\title{
Lean construction as an effective organization model in Arctic
}

\author{
Elena S. Balashova ${ }^{1}$, and Elizaveta A. Gromova ${ }^{2 *}$ \\ ${ }^{1}$ Peter the Great St. Petersburg Polytechnic University, Saint-Petersburg, Russia \\ ${ }^{2}$ Peter the Great St. Petersburg Polytechnic University, Saint-Petersburg, Russia
}

\begin{abstract}
In recent time, due to the sharp climatic changes, the Arctic attracts an increased interest of the world powers as a strategically important object. In 2013, the development strategy of the Arctic zone of the Russian Federation and national security for the period up to 2020 was approved by the President. In this strategy, the socio-economic development of the region in terms of improving the quality of life, expressed in the implementation of housing and civil engineering is very important. The goal of the study is to identify effective organization model of construction in the Arctic zone of the Russian Federation. Lean construction as a dynamically developing methodology abroad is analyzed. Characteristics of this organization model of construction meet the necessary requirements for the construction of various infrastructure objects in the Arctic. Therefore, the concept of lean construction can be an effective strategy of development of the Arctic regions of Russia as well as other Arctic countries.
\end{abstract}

\section{Introduction}

In recent years, the world community is characterized by a turbulent development of economy. In conditions of extremely high global competition a well-built state program of development and ability to respond quickly to the changes in the external environment come to the fore. So, recently, the Arctic is increasingly attracting the interests of the world powers. Global warming, which triggered a rapid decline of the ice area in the Arctic ocean, is able to release water from the Arctic ice in summer, according to the latest modeling software, by 2020. According to data released by the U.S. geological service in 2008, up to a quarter of the world's undiscovered oil and gas reserves are concentrated in the Arctic. And $80 \%$ of these reserves are hidden in the Arctic shelf. Taking into account the trend of melting ice and high mineral potential, the region is very promising.

The Arctic is becoming a strategic vector of Russia's development, both from the point of view of strengthening positions on the international arena and ensure the national interests. In the future, this region will be able to contribute to the economic growth of the country. In February 2013, the development strategy of the Arctic zone of the Russian Federation and national security for the period up to 2020 was approved by the President. Plans of expanding Russia's military presence in the Arctic is an essential part of this

* Corresponding author: lizaveta-90@yandex.ru 
document. But also the issues of ensuring sustainable socio-economic development of the Arctic zone of the Russian Federation occupy a significant place. The construction industry is a driver of economic growth. Therefore, the object of the research is the housing and civil engineering in the Arctic part of Russia.

The region has a number of features:

- extreme climatic conditions, including low temperatures, strong winds and ice cover in the waters of the Arctic seas;

- remoteness from basic industrial centers, high resource intensity and dependence of economic activities and livelihoods of supplies from other regions of Russia;

- low sustainability of ecological systems.

At the same time, the domestic construction industry is characterized by uncertainty of construction time, the project cost and scope of work. That's why, the choice of technology and construction organization are crucial. Lean construction represents a promising model of the systematic management of all stages of the life cycle of the construction project, which is focused on reducing the time and cost expenses.

The theoretical and practical issues of development of the effective models of construction organization from the point of lean manufacturing are explored by many scientists. Among them the following scholars are highlighted: L. Koskela (1992, 2000, 2002), G. Ballard (1994, 2000, 2003), J. Howell (1999, 2003, 2014), A. Mossman (2005, 2009). It is noteworthy that this concept has received wide recognition abroad, both theoretical and practical levels, possible methods of implementation are developed, the tools of lean construction are analyzed. In Russia, the spread of the concept is poorly expressed. The problems of applying the model of lean construction in the Arctic zone of the Russian Federation are quite undeveloped.

Thus, the objective of the study is to analyze the housing and civil engineering in the Arctic from a position of implementing the methodology of lean construction.

\section{Methods}

Lean construction is a kind of derivative of the lean production concept [1-7]. In the beginning of 1990-ies L. Koskela was one of the first who analyzed the application of the principles of lean production in construction industry [8-11]. As a result, he laid the foundation of lean construction. This concept is a management model that is similar to lean production in part of the pursued objectives, which are based on constant cost reduction, continuous quality improvement and optimization of the speed of material flow according to the logic of just in time. But it has several features in connection with the specifics of the construction field. One of the main distinguishing features is the predominant percentage of losses in construction compared with production [12] and a slightly different classification [13]. Losses in construction are along with the classical losses which were allocated by [14]: overproduction; waiting; unnecessary transportation; processing; inventory; unnecessary movement; production of defective products, the replacement is a monetary loss caused by the substitution of more expensive materials (with an unnecessary better performance), performing simple tasks by highly qualified staff or using high-tech equipment instead of the less technological; and the other related to the openness of construction sites (theft, vandalism, inclement weather, accidents). Another distinctive feature is the nature of the product movement: in industrial production, the products move through the stationary working stations, and in construction, the work areas move through stationary products [15]. Also, differential moment is a high degree of uncertainty of the construction project because of the scale of activity.

The Deming cycle (PDCA) [16] is the basis of the algorithm logics of improvement the processes of the lean construction. 
Lean construction uses the entire set of tools of lean production and in addition has a number of specific such as:

- the last planner system (the system of operational planning based on the principle "down-up" and covering a period of one week, i.e. weekly and daily schedules are built for two weeks, where the graphs of the first week are working (fully secured by the material resources), and graphs of the second week provide solutions to the logistics works of the second week. The indicator (PPC, percent plan complete) that shows what share of weekly work plan completed on time, is introduced to describe the quality of the development and implementation of schedules. This system is one of the most effective ways to improve construction efficiency through improving the processes of the planning and controlling.) [17-21];

- concurrent engineering (parallel execution of various tasks using multidisciplinary teams with the aim of obtaining the best products from the point of functionality, quality and performance);

- the planned conditions and working environment in the construction (this tool is necessary to match the conditions for execution of a task with capabilities of workers with the aim of preserving their health and safety).

Unlike traditional approaches to organization of construction, which are based on project management techniques, the concept considers the construction process as a value stream creation. Stages of construction constitute the stream logically replacing each other. At that time, in the framework of the established approach: the production process consists of the several subprocesses that transform a variety of resources at the entrance to the finished product at the output and that can be implemented and analyzed separately from each other.

Thus, the main advantages of the lean construction include:

- reduction of project turnaround time;

- reduction of construction costs;

- high quality of the completed construction objects;

— high degree of controlling of construction project.

\section{Results and discussion}

According to the development strategy of the Arctic zone of the Russian Federation and national security for the period up to 2020 one of the priorities is an integrated socioeconomic development of the region, which is provided, in particular, improving the quality of life of indigenous peoples and social conditions of economic activity in the Arctic. Accordingly, in order to improve the quality of life of people who are living and working in the Arctic zone of the Russian Federation, including indigenous small peoples, increase their level of social and cultural services and ensure positive demographic developments and necessary social conditions of economic activity are considered, among others, the following activities:

- housing development and upgrading of social infrastructure objects, including educational institutions, healthcare organizations and culture organizations;

- housing renewal and housing modernization, upgrade and modernization of the fixed assets of housing and communal services on the basis of modern energy saving technologies;

- active formation in the cities, small villages and towns new available for all segments of the population and mobile multifunctional cultural institutions.

The state program of the Russian Federation "Socio-economic development of the Arctic zone of the Russian Federation for the period till 2020" is the main mechanism for the 
implementation of the aforementioned strategy, in which the aim is the creation and development of the local livelihood systems in the region, where housing and civil engineering plays an essential role. Thus, this problem must be realized through the implementation of projects directly in the field of housing construction along with the construction of socially significant objects equipped with network engineering and technical support. Basis for the formation of the positive trends in the implementation of such projects is the financing on the required scale, focused on the mechanisms of the public-private partnership. By 2020 in the context of this task, the achievement of the following values of some targets is provided:

— average population of the Arctic zone will be 2341.2 thousand people;

- rate of the natural increase of the population of the Arctic zone (per 1000 persons) will grow by more than threefold and will amount to 9.5 persons per 1000 persons of the population;

— total area of living spaces will reach 25.9 sq.m in average per one resident.

\subsection{Features of housing and civil engineering in the Arctic zone}

The combination of extreme environmental conditions with low socio-economic development of the region predetermined the difficult conditions for construction. The process of housing and civil engineering has many engineering features. Objects have to be built on unstable terrain under which the soil is mixed with ice. In the permafrost the surface is constantly changing its structure. Built structures heat the soil, and it loses solidity, begins to melt and shift. For example, in Canada, which also represents the Arctic, the residents of two small towns were forced to leave their homes for this reason. Therefore, it is possible to build the foundation of buildings on permafrost, only by taking special measures to maintain constant temperature of the soil. The construction of the foundations must necessarily be accompanied by an engineering-geocryological investigations in order to adequately predict the behavior of soil during the construction and subsequent operating of buildings. Calculations of the thermal regime of soils are performed and the type of foundation is determined after the engineering studies. There are two principles on which the use of permafrost as the foundation of buildings is based. The first principle is the aspiration to maintain the permafrost in its natural state (the most popular and affordable solution). Under the second principle, a building is designed with the expectation that the foundation of the house will be in a thawing condition [22]:

1) in accordance with the first principle, the permafrost Foundation remains in its original state not only in the process of building construction, but during its subsequent operation. This principle is applied in situations where preservation of the frozen soil in its original state is cost-effective. The easiest way is to build a foundation on a sandy ground, which is not classified as plastic-frozen. For the latter cases, activities to reduce the temperature of the base to the calculated values are additionally provided, and possible plastic deformations of the base under the loading are considered in the calculations of the foundation. Following this principle mainly pile or pier foundations are satisfied. But, for example, strip foundation may also be the solution. The only one condition is to not give the top layer of soil to change its properties under the influence of heat from operated object. For this purpose, the underground is made cold, ventilated through the produhi in zabirka or the basement of the house. Also, a solid insulation layer with high insulation properties under the building can be performed. This will keep the soil in its natural state. Also, it is important to determine the depth of the soil. For different types of structures, its value is assigned separately: 
- for pile foundations, the depth of laying should not be less than $2 \mathrm{~m}$ greater than the thickness of the layer of soil that freezes and thaws seasonally. The calculation is done on that layer of the permafrost soil will provide the required resistance to compression;

- for all other types of foundations, the depth of laying is set greater than the thickness of the seasonal thawing soil at $1 \mathrm{~m}$;

- if the construction of the building on an artificial material with prescribed characteristics is designed, the depth of laying the soles is not standardized and it is based on the conditions of construction;

2) the second way is used less frequently and under conditions when the soil at the construction site is not heaving or subsidence and when in terms of temperature fluctuations, the soil deformations do not exceed the maximum permissible values. In this case, it is necessary either to thaw out the soil before construction of the foundation, or make all important calculations, and to assume that the foundation will thaw during the operating of the building. Construction of the building's basis involves the calculation of the depth of laying of the foundation sole in the comprehensive assessment of the thickness of the seasonally freezing soil and level of ground waters, focusing on the zone of thawing. And it will be formed in the subsequent operating of the building.

A specific choice is made by comparing the technical and economic calculations and the effectiveness of the considered solutions.

The necessity of application of pile foundations and thermo-insulating and innovative energy-intensive materials for construction of buildings walls in severe climatic conditions creates significant costs. For many areas in the Arctic region, such construction becomes uneconomical. For example, in Norilsk, the price of $1 \mathrm{sq}$. $\mathrm{m}$ of real estate is about $22-26$ thousand rubles on the secondary market and the cost of construction of 1 sq. $m$ in low-rise apartment building is about 75 thousand rubles. The example is significant from the point of view that Norilsk is allocated from the set of settlements included in the Arctic zone of the Russian Federation, by positive trend in population (in 2012 - 177273 people; in 2013 177738 people; in 2014 - 176559; in 2015 - 176251 people; in 2016 - 177428 people, according to the data of the Federal state statistics service of the Russian Federation).

In the Arctic, the accumulation of damages in the protective and decorative coverings and construction materials happens many times faster than the Average strip of Russia, because of the rapidly flowing vapor condensation processes under changing temperature and humidity conditions. Intense destruction is caused by the volume expansion of water in construction materials when it is freezing. Errors of the design, construction and operating of real estate quickly manifest. Correction of defects in the Arctic zone costs many times more expensive than in other areas [23]. In turn, the physical deterioration of buildings quite early reaches critical values, which mean the assignment to the category of dilapidated housing. The overhaul of such objects is difficult and often economically inefficient.

Therefore, the construction in the Arctic can be described as a costly project that requires the highest quality and rapid pace of work and, consequently, reduced construction time compared to the objects located in more favourable conditions.

The significant role in the implementation of this organization model of construction is given to the last planner system. The project of the low-rise residential building in Norilsk, which takes into account the characteristic features of the Arctic in relation to construction and installation works is presented in figure 1 . 
The master plan of the project. The construction of the foundation. Purchase and delivery of construction structures. Installation. Final finishing of the building. The construction of safe accommodation one building of low-rise building without the destruction, provided with a protective and decorative covering, and erected on a grillage.

The plan phase of the project (should do). Installation of internal partitions. Installation of a roof subject to strong winds.

"Foreseeing" project plan (can do). The construction of outer walls of thermo-insulating materials.

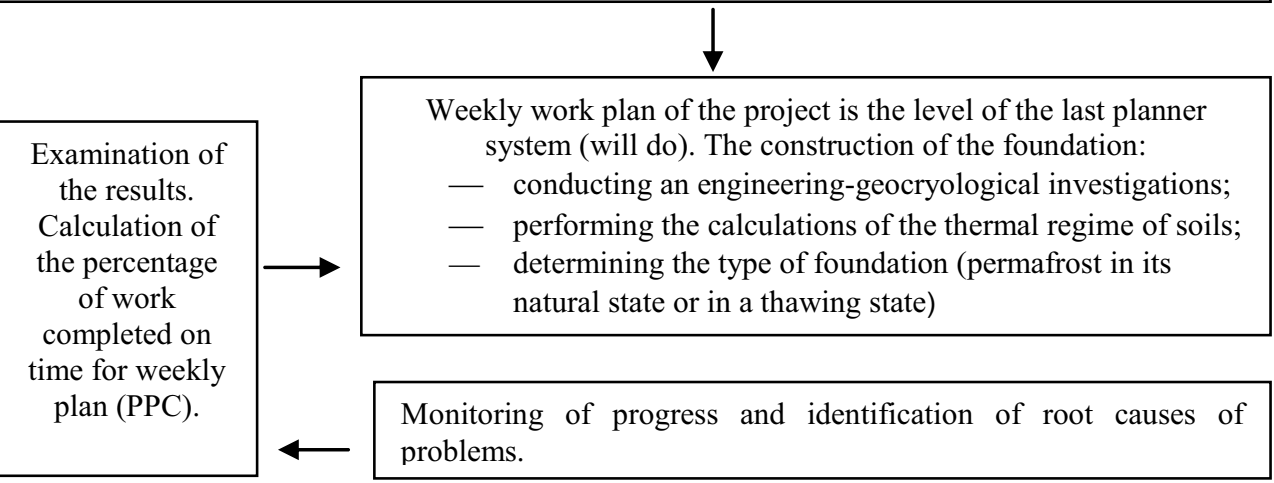

Fig. 1. The scheme of operational planning of construction, developed by the authors

In summary, it is possible to highlight the key features of housing and civil engineering in the Arctic zone of the Russian Federation:

- high cost of construction, which pushes private developers, along with insufficient state financing;

- required high professionalism of employees in terms of the design and construction of objects related to the effects of harsh climatic conditions;

- execution of typical projects;

- limited construction time.

Obviously, the main features of the concept of lean construction meet adequately to requirements, that apply to models of the housing and civil engineering in the Arctic regions of the Russian Federation and they are able to reach the target results. Due to the state support of development of the Arctic at the highest level, the issue of progress of infrastructure of life support for the population of the region, consisting for the most part in the development of residential objects and socially significant objects, is reduced to the rational methodology of construction organization. Certain features of lean construction contribute to a new, large-scale development and accelerated infrastructural development of the region.

\section{Conclusions}

Summing up the results of the study, the following conclusions should be allocated:

- high degree of importance of the Arctic as a strategic object is underlined; 
- issues of socio-economic development of the Arctic zone of the Russian Federation in part of life-support systems creating are actualized;

- features of the housing and civil engineering in the Arctic zone of the Russian Federation are systematized;

- lean construction, which is aimed at reducing costs and construction time, along with high quality construction, has all the prerequisites to become a breakthrough development strategy;

- lean construction in the context of the Arctic regions may become the first large-scale example of implementation of this concept in Russia.

In summary, lean construction is a promising way of organizing housing and civil engineering both for the Russian part of the Arctic and its foreign parts.

\section{References}

1. G. Ballard, G. Howell. Implementing lean construction: Improving downstream performance. Lean construction. Balkema, Rotterdam, Netherlands. 111-125 (1997)

2. J. Howell. Lean construction, Public Infastructure Bulletin. 1(9) (2014)

3. V.A. González, R. Sacks, I. Pavez, M. Poshdar, L. Ben Alon, V. Priven. Interplay of Lean Thinking and Social Dynamics in Construction. In: Proc. 23rd Ann. Conf. of the International Group for Lean Construction. Perth, Australia, July 29-31, 2015. 681690. (2015)

4. O. Salem, J. Solomon, A. Genaidy, I. Minkarah. Lean Construction: From Theory to Implementation. Journal of Management in Engineering. 22(4). 168-175 (2006)

5. G. Howell. What is Lean Construction. Proceedings of the Seventh Conference of the International Group for Lean Construction (1999)

6. A. Mossman. Why Isn't The UK Construction Industry Going Lean With Gusto?. Lean Construction Journal. 5(1). 24-36 (2009)

7. S. Belayutham, V.A. Gonzalez. Process Complexity at the Pre-construction Stage: A Lean Based Solution. Proceedings of the 4th New Zealand Built Environment Research Symposium (NZBERS). Auckland, New Zealand (2014)

8. L. Koskela. An Exploration Towards a Production Theory and Its Application To Construction. Espoo, Finland, VTT Publications, 296 (2000)

9. L. Koskela. Application of the New Production Philosophy to Construction, Technical Report No. 72, CIFE, Stanford University, CA (1992)

10. A. Alsehaimi, L. Koskela. Critical evaluation of previous delay studies in construction. Proceedings of the 8th International Postgraduate Conference, Prague (2008)

11. S. Bertelsen, L. Koskela. Construction beyond lean: a new understanding of construction management. Proceedings of the 12th annual conference in the International Group for Lean Construction, Elsinore, Denmark (2004)

12. R.F. Aziz, S.M. Hafez. Applying lean thinking in construction and performance improvement. Alexandria Engineering Journal. 52. 679-695 (2013)

13. C. Formoso, L. Soibelman, C. De Cesare, E. Isatto, Method of Waste Control in the Building Industry, Proceedings ICLG-7, University of California, Berkeley, CA, USA. 325-334 (1999)

14. T. Ohno. Toyota Production System. Productivity Press (1988) 
15. Ye.A. Chernykh. Primeneniye printsipa potoka v berezhlivom stroitel'stve [Application of the principle of flow in lean construction]. Quality management. 2. 102-121. (rus) (2010)

16. E. Deming. Out of the crisis. Cambridge MA: MIT Press (1982)

17. G. Ballard. The last Planner System of Production Control. University of Birmingham, Uk (2000)

18. A. Mossman, Last Planner Overview: Collaborative Production Planning, Collaborative Programme Coordination, Lean Construction Institute, UK (2005)

19. G. Ballard. The Last Planner. Northern California Construction Institute, Monterey, CA (1994)

20. D. Bhargav, H. Juho-Pekka, L. Koskela. Exploring the Recurrent Problems in the Last Planner Implementation on Construction Projects. Proceedings of the Indian Lean Construction Conference (ILCC 2015) (2015)

21. G. Ballard, G.A. Howell. An update on last planner. In Proc., 11th Annual Conf., International Group for Lean Construction, Blacksburg, VA (2003)

22. Smirnov K. Stroitel'stvo v vysokikh shirotakh. Printsipy, vozmozhnosti i perspektivy [Building in high latitudes. The principles, opportunities and prospects]. Proceedings of the I Russian architectural competition with international participation "Green project» (2015)

23. Y.A. Varfolomeev Osobennosti proyektirovaniya i stroitel'stva maloetazhnykh domov $\mathrm{v}$ Arktike [Features design and construction of low-rise buildings in the Arctic]. Arctic and Nord. 17. 28-43. (rus) (2014) 